\title{
REASSESSING WHITMAN'S HEGELIAN AFFINITIES
}

\author{
BRIAN BRODHEAD GLASER
}

FROM THE 1920s until the 1960s, as Millie D. Jensen demonstrates in her 1964 essay, "Whitman and Hegel:The Curious Triplicate Process," the quiet controversy about when Whitman first became aware of the philosopher spurred some advances into the question before its appeal seemed to disappear for a time. ${ }^{1}$ The facts are suggestive but do not allow a precise answer. Two anthologies which came into print around the same time as the poem that would eventually be known as "Song of Myself," Frederic H. Hedge's Prose Writers of Germany (1847) and Joseph Gostick's German Literature (1854), were likely the main sources of Whitman's exposure to the thought of Hegel before 1879, but it is unclear when he read them. Aside from his references to the philosopher in Democratic Vistas, there is nothing to suggest that during this period he sought more knowledge about him from the groups of American devotees which began to congregate in the second half of the century. Among Whitman's notes a short series of entries titled "The Sunday Evening Lectures" discusses Hegel and German-language philosophy, and, though it is generally agreed that these notes were written some time in the late 1860 s, there is no firm evidence for a date. It is clear, however, that Whitman's engagement with Hegelian thought has two phases, the first coming between 1868 and 1871 when he was at work on Democratic Vistas and the second ten years later, when he met in St. Louis with the Hegelian William Torrey Harris.

In addition to determining what Whitman learned about Hegel and when, interpreting their relation also often involves recognizing that Whitman from the outset wanted to use Hegel to frame and project the legacy of a poetics which was already a decade old. In this respect even Whitman's own account of his Hegelianism in these years ought to be read as a proleptic rather than retrospective description, since he was turning to Hegel not for an explanation of the power of his poetry's emergence but to explain its role in the social life and future of America. With the claim that "only Hegel is fit for America," Whitman pretty clearly asks the philosopher to stand in for himself when his poetics are pressed to a new level of involvement with politics. ${ }^{2}$ 
This connection between Whitman and Hegel — politically focusedI take to be the widely accepted one at the time of this writing. As Kathryne V. Lindberg pointed out in her powerful 1991 critique, "Whitman's 'Convertible Terms,'” the range of problems emerging from Whitman's pretense to a widely representative selfhood have only come under scrutiny since theory has developed terms with which to attack the Hegelian affinities Whitman claimed. Lindberg puts it most concisely this way:

With successive self-presentations, from the representative "I" to a "Me/Myself" that encloses all the questions and answers of the philosophers and priests of the past, the Whitmanesque self loses its historical specificity in order to become transcendent or, like the Hegelian world historical spirit, translatable-yet Whitman also insists on being "untranslatable." Just so, mergers of chauvinism and egotism into what Quentin Anderson has termed the "imperial self" [1971] were already apparent in the 1855 preface. $^{3}$

For the lines of contemporary theory most concerned to articulate the importance of differences, Whitman's problematic self-conception can be traced to 1855 but only dismantled once he begins to make explicitly political and philosophical claims - as, in Lindberg's view, when he brings together in Democratic Vistas his ideal of the highest poetry as speaking for all with a rough notion of the dialectic in order to claim the importance of Hegel for recognizing how Americans must improve on their undemocratic inheritance of English literature. So Lindberg's critique of Whitman's Hegelianism culminates in a deconstruction of the poem which she understands his later prose to explicate:

The typical personality of Whitman's poetic and critical corpus is wide, amorphous, if not aleatory. His American readers, so ready to reject history and politics in the name of an idealized individualism, have a special stake in appropriating or interpreting the self-the selves-he offers. "Song of Myself" alone is broad enough for most everyone to identify something of him or herself in the catalog of American types that Whitman calls "myself." The resulting construct - variously "Whitman," "I," "Me," "the real Me Myself," and even "you"- essentializes individualism and liberates the self from the very socioeconomic contingencies, the facticity, it seems to contain. (266)

It is powerful and prevalent theoretical criticism Lindberg makes of Whitman's "construct," one stated in somewhat different terms by Philip Fisher and Allen Grossman.

More recent work has continued to focus on the politically problematic dimensions of Whitman's work when seen in a Hegelian context, albeit with a less explicitly theoretical orientation. George B. Handley puts it this way, in his 2007 New World Poetics:

Such yearning for a complete break from the Old World has paradoxically fostered a Hegelian belief in the inevitable and utterly reliable directive of Western history and a 
paradoxical lack of interest in social and environmental particulars. Of these three New World poets [Whitman, Neruda, and Walcott] there is no doubt that Whitman is the most attracted to this kind of Hegelian thinking. ${ }^{4}$

Critics are not entirely in agreement about whether the difference-leveling impulse in Whitman's later political writings invoking Hegel signals a change in his thinking or betrays a consistent point of view, but alongside Lindberg's and Handley's studies we may place the findings of Thomas F. Haddox, who concludes in a 2004 essay that:

Whitman's growing interest in the philosophy of Hegel, particularly evident in Democratic Vistas, suggests that he believes history in any meaningful sense to be at an end, that the democratic millennium is at hand, and that it will, despite all appearances to the contrary, progress unstoppably to its complete realization - a position all too amenable to conservatism and complacency. ${ }^{5}$

As the contrast between Handley's and Haddox's positions makes clear, there is no pure consensus on what name should be given to the problematic dimensions of Whitman's Hegelianism, but it is clear that it involves, among other things, unreflecting conservatism, indifference to diversity, and a misunderstanding of what is powerful about history-all charges that threaten a more robustly democratic picture of Whitman that has its support in much of his work.

Handley's treatment of the Whitman of Democratic Vistas as divided between an Hegelian and a much more modern orientation may turn out to be the most useful to emerge from considerations of the question. But before we let the question fall silent for another spell, I would like to offer a further possibility. What drew Whitman to Hegel was a sense of their affinity as thinkers on the subject of freedom. Looking at the poem that would become "Song of Myself" and Hegel's Phänomenologie des Geistes (hereafter, Phenomenology of Spirit) in the context of ideas of freedom they were written out of and against, one can discern an important similarity between Whitman's self-representation and Hegel's idea of Geist or spirit.

Stephen John Mack has recently called the opening lines of "Song of Myself" "an elaboration of Whitman's conception of natural, democratic selfhood." $\mathrm{He}$ elaborates on this understanding by quoting at some length from the pragmatist George Herbert Mead, including this passage:

No hard-and-fast line can be drawn between our own selves and the selves of others, since our own selves exist and enter as such into our experience only in so far as the selves of others exist and enter into our experience also. The individual possesses a self only in relation to the selves of the other members of his social group. (25) 
I think that Mack is accurate in his description of Whitman's understanding of the self and that he is right to locate its first articulation or expression in Whitman's work where he does. I would add to Mack's argument that this understanding of the self is not only "pragmatic" but also Hegelian, and, further, that this understanding of the self constituted a breakthrough for Whitman into a new understanding of freedom.

For Whitman in 1850, as one can tell from his political poems of the period, "Dough-Face Song" and "Blood Money," the price of sociality seemed to involve the reduction of the value of the individual to something expressed in hard currency. Society is based on the demand for exchange, and exchange is the enemy of the ideal of freedom. ${ }^{7}$ Such a notion of liberty we might call, following Isaiah Berlin and others, a negative conception of freedom, the idea that freedom is always freedom from social constraints and controls. If he was inclined to believe this throughout the 1840 s, the debates which led up to the Compromise of 1850 only intensified Whitman's commitment to this point of viewindeed the autonomy of the individual had become so essential to his notion of freedom that his poetry could only relate to this ideally free self as either the satirical voice of a social authority who would undermine its independence or in an address to an individual who had been so traduced by the interests of the community as to be dumbstruck. By the early 1850s, the autonomous individual in Whitman's poetry had become so idealized that he was unable to speak for himself.

This is the context in which I think we can recognize how significantly Whitman's notion of freedom changed over the four years between the publication of these poems and the promise of mutual belonging which opens his 1855 work. One mark of the continuity of his thought is the trace in the later work of his more combative assertions of freedom-in one paragraph of the preface he mentions both eponymous scourges of his Free-Soil poems, "bloodmoney" and "doughfaces." Yet in this preface, as throughout the subsequent poem, Whitman's motive is not to protest but to articulate his new ideal of poetry and its actual context in the United States. Freedom has become a question not of autonomy but of having one's chosen identity recognized by others. At the beginning of the work he says that American democracy requires "the practical acknowledgement of the citizens of one state by the citizens of all other states" and the "terrible significance of their elections" and that, for all of the discouraging compromise involved in such negotiations, "these too are unrhymed poetry" which "awaits the gigantic and generous treatment worthy of it" ( $L G 1855$, iii). In this new vision of American democracy, collectivity is not antithetical to freedom but the ground of it. 
In order to show how the Phenomenology of Spirit anticipates Whitman's changing conceptualization of freedom in the years leading to his achievement in 1855, I need as briefly as possible to set Hegel's breakthrough work in its own intellectual context. For this I rely on the summary of what is distinctive in Hegel's thought as has been most sympathetically and comprehensively articulated by the philosopher Robert Pippin. In Modernism as a Philosophical Problem: On the Dissatisfactions of European High Culture (1991), Pippin sketches out how Hegel's thought is original for its solution to the problematic question of freedom for Enlightenment thinkers:

Let us assume that early modern philosophers understood modern liberation and a quest for independence as freedom from religious and traditional authority and a new, hardheaded allegiance to "nature" as an ultimate standard, whether understood empirically or rationally, that Kant effectively criticized such appeals to nature and reinterpreted the true Enlightenment as the human subject's knowledge of its own self-legislating activity, and that Hegel showed that the form of such contributions by the subject could not be determined by a transcendental analysis, but required some sort of a continuous historical narrative. ${ }^{9}$

A quite similar picture emerges in Charles Taylor's Hegel (1975) and a number of recent studies of the concept of freedom in Hegel's thought, including Paul Franco's Hegel's Philosophy of Freedom (1999) and Alan Patten's Hegel's Idea of Freedom (1999). As the relation is generally read, Hegel asserted against Kant that no matter how distinct from divine revelation and instinct the subject's self-knowledge might be, a subject could never become substantial enough to understand the freedom he creates for himself without some account of his past. This response to Kant is taken to be the intellectual center of Hegel's so-called Jena period, an era named for the city and university where he wrote The Phenomenology of Spirit in 1806 and 1807.

As Pippin presents the issue which distinguishes Kant from Hegel and creates the problematic idea of freedom for the post-Enlightenment tradition, "the great, single modernity problem in the German tradition, is 'autonomy"' (12). For Kant, freedom involves the discovery that the laws which establish one's freedom emerge from one's knowledge of one's own being, as separate from both the natural world and society. The principle by which one comes to recognize these laws is called reason. Because of Kant's re-definition for philosophy of the nature of freedom, Pippin writes:

the appropriate question at issue (asked many, many times after Kant) becomes whether such a subject can be so radically independent or self-determining, and especially whether its results can be said to apply universally to any agent attempting such critical freedom, 
Hegel's notion of spirit arises from his attempt to answer this question. For as The Phenomenology of Spirit presents the issue, history is meaningful to philosophy as the process by which human consciousness has graduated to more and more powerful understandings of its freedom - as its awareness broadens, it evolves from mere understanding to self-consciousness to reason, at each point progressing in its development by turning to think its own past from its newest perspective. From Hegel's point of view, what is substantially new in his own philosophy begins when the mind, from the perspective of reason, must turn to tell the story of its origin. For then it comes to find that self-definition by rational introspection cannot explain all that had been hoped.

In the Phenomenology of Spirit, reason first recognizes the limits of its own capacity to authorize the laws in relation to which the self is free at the very end of the fifth chapter, in a subsection entitled "Gesetzprüfende Vernunft" ["Reason as testing laws"]. ${ }^{10}$ In the passage immediately before this, Hegel has argued that reason by itself cannot give positive content to laws, and so its capacity to legislate must be confined to how it can validate them. To put such a process in motion he tests this idea as an example: "Es ist die Frage, soll es an und für sich Gesetz sein, daß Eigentum sei" ( $P G, 279)$ ["Ought it to be an absolute law that there should be property?" (PS, 257)]. Reason is by definition obliged to answer this question in absolute terms, Hegel notes first, because laws are for it not a question of utility for other ends but rational necessity. Its procedure for testing such a law then can only be to ask whether there is an inherent contradiction in the concept of property as a law or right. And he claims simply that there is nothing in the concept of property which contradicts itself. However, he notes, this would also be the case with making property illegal.

To come down on one side or the other, Hegel then asks reason to consider the practical possibility of banning private property by allowing the individual to possess only those things which are deemed necessary. But, Hegel argues, this regulation is antithetical to the nature of the individual, who will experience his own claim on resources to have a priority which they do not have from a more distant perspective. Yet the only alternative way of outlawing property is to regulate the distribution of goods to the individual based on need, which involves no universal standard for defining what counts as need and so leaves no stable way to arbitrate inevitable conflict. However logically sound the prohibition, there can be no practical way of prohibiting private property that does not end up requiring arbitrary solutions to its own lived contradictions. Therefore, Hegel argues, extending the range of considerations from what he calls the formal issue of logical contradiction to the way such a 
law would be "in Momente aufgelöst" ["resolved into its moments"] in social life reveals that reason may be able to determine the legitimacy of at least some laws, at least negatively ( $P G, 279 ; P S, 258)$.

But there is a catch to extending the claim of reason this way. For if we look at how the legal right of private property would resolve into its moments in social life, it also turns out to be self-contradictory. Hegel's argument on this point could be stronger, in part, as Alan Patten points out, because he is ultimately sympathetic to a view of property as essential to an individual's development, an argument made in The Philosophy of Right. But his claim at this point goes far enough to substantiate his critique of reason as a tester of laws - he states that while the condition of the right of ownership is social recognition as an individual, ownership itself is a re-definition of the object on asocial terms. ${ }^{11}$ Vulnerable as this argument is rhetorically, the point for Hegel is that it demonstrates a logical contradiction which appears at the heart of the idea of property only once the concept must be viewed in social or practical terms. His interest is not to resolve the question but to show why determining the legality of property cannot simply be left to reason as a process of logical deduction:

Eigentum widerspricht sich daher nach allen Seiten ebensosehr als Nichteigentum; jedes hat diese beiden entgegengesetzten, sich widersprechenden Momente der Einzelheit und Allgemeinheit an ihm.-Aber jede dieser Bestimmtheiten einfach vorgestellt, als Eigentum oder Nichteigentum, ohne weitere Entwicklung, ist eine so einfach als die andere, d. h. sich nicht widersprechend.--Der Maßstab des Gesetzes, den die Vernunft an ihr selbst hat, paßt daher allem gleich gut, und ist hiermit in derTat kein Maßstab. $(P G, 280)$

Consequently, property is just as much an all-round contradiction as non-property; each contains within it these two opposed, self-contradictory moments of individuality and universality. But each of these determinatenesses when thought of as simple, as property or non-property, without explicating them further, is as simple as the other, i.e. is not self-contradictory. The criterion of law which Reason possesses within itself fits every case equally well, and is thus in fact no criterion at all. (PS, 259)

Deciding whether laws are legitimate must not be a question of determining whether they are inherently self-contradictory, because it is the nature of laws in modern life to respond to the contradictory pressures of collectivity and individuality. And so to a very significant extent reason is not capable of giving coherent definition to freedom or its limits in social life.

But how then to assess the validity of laws? And what is freedom if it is not autonomy, the capacity to derive one's standards of behavior via introspection? These are the questions that lead Hegel to insist on philosophy as a vehicle of spirit rather than reason. He claims that a 
purely negative definition of freedom, an exclusive focus on autonomy, involves a misunderstanding of what it means to be an individual: "das Prüfen der Gesetze, das Bewegen des Unbewegbaren und den Frevel des Wissens bedeutet, der sich von den absoluten Gesetzen frei räsonniert und sie für eine ihm fremde Willkür nimmit" ( $P G, 281)$ ["testing the laws, moving the immovable, means the insolence of a knowledge which argues itself into a freedom from absolute laws, treating them as an alien caprice" $(P S, 260)]$. Shortly beforehand, of course, he has demonstrated that it is possible for us to adopt a perspective in which any law seems self-contradictory and so not valid. But at our most thoughtful, he says, we do not know ourselves as an alienated, logic-chopping subject-we participate in what he calls the "sittliche Substanz" ["ethical substance"] of a community, through which we have an immediate understanding of the difference between right and wrong ( $P G, 280 ; P S, 259)$. The question of what should or should not be an individual right has to do not with legal justification or logical consistency but with the way one's ethical sense has been shaped by communal life. Laws are simply one expression of ethical substance, and so have a special force for their community, a force which is not subject to dialectical tensions with the principle of individuality:

Sie sind. Wenn ich nach ihrer Entstehung frage, und sie auf den Punkt ihres Ursprungs einenge, so bin ich darüber hinausgegangen; denn ich bin nunmehr das Allgemeine, sie aber das Bedingte und Beschränkte. Wenn sie sich meiner Einsicht legitimieren sollen, so habe ich schon ihr unwankendes Ansichsein bewegt und betrachte sie als etwas, das veilleicht wahr, veilleicht auch nicht wahr für mich sei. Die sittliche Gesinnung besteht eben darin, unverrückt in dem fest zu beharren, was das Rechte ist, und sich alles Bewegens, Rüttelns und Zurückführens desselben zu enthalten. $(P G, 283)$

[Laws] are. If I inquire after their origin and confine them to the point where they arose, then I have transcended them; for now it is I who am the universal, and they are the conditioned and limited. If they are supposed to be validated by my insight, then I have already denied their unshakeable, intrinsic being, and regard them as something which, for me, is perhaps true, but also is perhaps not true. Ethical disposition consists just in sticking steadfastly to what is right, and abstaining from all attempts to move or shake it, or derive it. (PS, 261-262)

The insight in this passage which Hegel chooses to carry forward in the Phenomenology of Spirit is not that the individual ought not question the authority of laws but that knowing what is right for the individual is not ultimately a question of laws at all. The point of calling laws unshakeable is not that they do not change but that the reason of their creation and their possible amendment cannot be found solely through the insight of the individual but in the trans-subjective social power by which they first of all are. 
Situated in the final paragraph of the chapter on reason, just before his shift to the concept he took to be his essential contribution to philosophy, Hegel's example of what is involved in accepting such a view of rightness puts the social issue of freedom in its starkest terms. Hegel's argument at this point is involved with the question of the social meaningfulness of one person's freedom, and it turns on the issue of how to negotiate the universal right of property with the individual's demand not to be constrained by alien laws. The question he asks is: how might one justify not returning what another has good legal claim on as his property?

Es wird ein Depositum bei mir gemacht, es ist das Eigentum eines Andern, und ich anerkenne es, weil es so ist, und erhalte mich unwankende in diesem Verhältnisse. Behalte ich für mich das Depositum, so begehe ich nach dem Prinzipe meines Prüfens, der Tautologie, ganz und gar keinen Widerspruch; denn alsdann sehe ich es nich mehr für das Eigentum eines Andern an; etwas behalten, das ich nicht für das Eigentum eines Andern ansehe, ist vollkommen konsequent. Die Änderung der Ansicht ist kein Widerspruch, denn es ist nicht um sie als Ansicht, sodern um den Gegenstand und Inhalt zu tun, der sich nicht widersprechen soll. So sehr ich-wie ich tue, wenn ich etwas wegschenke-die Ansicht, daß etwas mein Eigentum ist, in die Ansicht, daß es das Eigentum eines Andern ist, verändern kann, ohne dadurch eines Widerspruches schuldig zu werden, ebensosehr kann ich den umgekehrten Weg gehen.-Nicht darum also, weil ich etwas sich nicht widersprechende finde, ist es Recht; sondern weil es das Rechte ist, ist es Recht. (PG, 283)

Suppose something has been entrusted to me; it is the property of someone else and I acknowledge this because it is so, and I keep myself unfalteringly in this relationship. If I should keep for myself what is entrusted to me, then according to the principle I follow in testing laws, which is a tautology, I am not in the least guilty of contradiction; for then I no longer look upon it as the property of someone else: to hold on to something which I do not regard as belonging to someone else is perfectly consistent. Alteration of the point of view is not contradiction; for what we are concerned with is not the point of view, but the object and content, which ought not to be self-contradictory. Just as I can - as I do when I give something away-alter the view that it is my property into the view that it belongs to someone else, without becoming guilty of contradiction, so I can equally pursue the reverse course. It is not, therefore, because I find something is not self-contradictory that it is right; on the contrary, it is right because it is what is right. (PS, 262)

Nothing in reason can allow us to distinguish our objection to a law out of conviction from our objection on the grounds of a false principle because laws are both defensible and vulnerable on the question of selfcontradiction, depending on the perspective one adopts. So, in Hegel's view, one should return what belongs to someone else because one is a member of a community for which private property is a right and so is protected not only by law but by each individual's sense of commit- 
ment to a point of view from which that legal right can be consistently recognized.

From this discussion, it is not too hard to see why in Hegel's work the first of the three phases of the development of spirit in social life is the one in which self-explanations have to do not with principles but with identities, a domain Hegel calls "die sittliche Welt" ["the ethical world"] $(P G, 288 ; P S, 267)$. Spirit is an ethical substance insofar as the individual selves which constitute it both acknowledge their social construction and take up possession of identities in the social nexus that defines these identities. So in an intellectual world illuminated by this concept, in contrast with a realm guided by the ideals of rational introspection, freedom is to be understood not as autonomy from external laws but rather as the capacity to inhabit positions of participation in social life:

Die Substanz und das allgemeine, sichselbstgleiche, bleibende Wesen,--ist er der unverrückte und unaufgelöste Grund und Ausgangspunkt des Tuns aller und ihr Zweck und Ziel, als das gedachte Ansich aller Selbstbewußtsein.-Diese Substanz ist ebenso das allgemeine Werk, das sich durch das Tun aller und jeder als ihre Einheit und Gleichheit erzeugt, denn sie ist das Fürsichsein, das Selbst, das Tun. $(P G, 285)$

Spirit, being the substance and the universal, self-identical, and abiding essence, is the unmoved solid ground and starting-point for the action of all, and it is their purpose and goal, the in-itself of every self-consciousness expressed in thought. This substance is equally the universal work produced by the action of all and each as their unity and identity, for it is the being-for-self, the self, action. (PS, 264)

Confusing as the terminological distinctions between being-in-itself and being-for-itself may seem at a first reading, the two aspects of the substance of spirit - one as the ground of meaningful selfhood, and the other as the product of the work done by all who emerge from this ground - are a crucial dyad, because of the way Hegel uses them to explain the justification of individual actions in the domain of spirit. For in Hegel's analysis, an ethics informed by the notion of spirit can offer a much more ample notion of human freedom than one based on reason precisely because one's claims on rights are circumscribed not by the Kantian criterion of universal non-contradiction but by a sympathetic societal acknowledgement of the importance of self-interest:

Als die Substanz ist der Geist die unwankende gerechte Sichselbstgleichheit; aber als Fürsichsein ist sie das aufgelöste, das sich aufopfernde gütige Wesen, an dem jeder sein eigenes Werk vollbringt, das allgemeine Sein zerreißt und sich seinen Teil davon nimmt. Diese Auflösung und Vereinzelung des Wesens ist eben das Moment des Tuns und Selbsts aller; es ist die Bewegung und Seele der Substanz und das bewirkte allgemeine Wesen. Gerade darin, daß sie das im Selbst aufgelöste Sein ist, ist sie nicht das tote Wesen, sondern wirklich und lebendig. (PG, 285) 
As substance, Spirit is unshaken righteous self-identity; but as being-for-self it is a fragmented being, self-sacrificing and benevolent, in which each accomplishes his own work, rends asunder the universal being, and takes from it his own share. This resolving of the essence into individuals is precisely the moment of the action and the self of all; it is the movement and soul of substance and the resultant universal being. Just because it is a being that is resolved in the self, it is not a dead essence, but is actual and alive. (PS, 264)

Self-interest, from such a perspective, is not what is to be expunged via rational introspection but rather the abstract matter out of which the meaningfulness of one's own selfhood can ultimately be composed.

Under the aspect of the Hegelian notion of spirit, then, freedom cannot be defined merely in negative terms. Individual freedoms are not achieved by extricating oneself from societal constraints, but instead by moving through alienation from available forms of selfhood into an identification with them. Laws are not checked against an independent source of rationality; they are felt as one form of delineation of the kind of person one finds oneself able to be. And the individual self is understood not as a fundamentally pre-social autonomous core but as a space into which one may, through identifications, draw more and more personal modes of being.

This is not yet a fully dialectical view of self-consciousness-but it is the distinctly post-Kantian understanding of the nature of the self that makes such a dialectic possible. Staying with Whitman as the inaugurator of such a tradition in American literature involves focusing on what is in retrospect perhaps the most problematic link between Whitman's notion of mutual belonging and Hegel's conception of spirit. For the spot at which this connection seems most strongly stated in the beginning of the sixth chapter of the Phenomenology comes where Hegel, like Whitman, defines the furthest reaches of spirit in the starkest terms of closure, the Volk: "Der Geist ist das sittliche Leben eines Volks, insofern der die unmittelbare Wahrheit ist, — das Individum, as eine Welt ist" ( $P G$, 286) ["Spirit is the ethical life of a nation in so far as it is the immediate truth - the individual that is a world" (PS, 265)]. Needing, as Whitman did, to define the community inside of which one's identifications would be meaningful, Hegel makes the same conclusion as the poet: the largest shape which spiritual selfhood can take is the body of a community. One may escape the pressure to define a community's laws in terms of an autonomous rationality, but one cannot define an actual ethical sphere based on identifications without some horizon of exclusion.

I think it is important to note in retrospect that what drew both Hegel and Whitman to conceive of the construction of the self in terms of a community was that it offered them the largest gathering of selves among which a dialectical commerce could be imagined. And it is with this concern for amplitude that Whitman's own version of ethical sub- 
stance shows a democratic dimension that Hegel can perhaps help us to identify. As an instance of what an Hegelian ethics of identification gives to "Song of Myself," return to these lines from near the end of the poem:

Listener up there! Here you .... what have you to confide to me?

Look in my face while I snuff the sidle of evening,

Talk honestly, for no one else hears you, and I stay only a minute longer.

Do I contradict myself?

Very well then . . . . I contradict myself;

I am large . . . . I contain multitudes. ( $L G 1855,55)$

Even as he invites the national individual - his poetry's "you" - to share in every atom of his being he insists that he is also just about to be entirely somewhere else. And then he offers this contradictory self-staging as evidence of his capacity to enfold the "you" all the more abundantly. It is in this way that it seems to me illuminating to see Whitman's attempt to absorb tensions between the individual and the collective as an effort to make actual the voice of what Hegel calls the "ethical substance" by which personal freedoms become meaningful (PS, 262). Freedom for both writers has to do not with articulating for oneself the terms on which one participates in society but rather with recognizing that responding to the address to subjects, the call to the "you," is a condition for the capacity to confide or give to another what has not yet been reached by such a call. Indeed, as Whitman expresses the process, a further consequence of this openness is to be able to identify with the way this other maintains the dynamism of selfhood by seeking out new modes of being which its interconnected structure allows it to contain. Reading Whitman's breakthrough on Hegelian terms, we might say that the self's invitation to mutual belonging is a signal that the self is not ultimately alienated from its cultural ground but rather can only be truly free insofar as it might be or become a shareable way of living.

In this way I think Hegel helps to illuminate one of the insights that was radically new for Whitman in his 1855 poem. And looking at such a relation also allows us to see in turn how living with Kant's notion of autonomy pressed Hegel to this idea-for without some notion of ethical substance there can be contentious legislative processes but no stable way of assessing any law's relative claim to being just. Perhaps one need not take the case for the similarity in the two men's work beyond noticing that a good deal of Whitman's frustration as a political poet in the 1850 s had to do with the fact that his ideal of freedom as absolute self-determination gave him a compelling position from which to write against the Fugitive Slave Act but could also be appropriated by Henry Clay to claim that such an argument expressed a merely northern interest. 
Unlike Whittier, Whitman did not persist in writing protest poemsbut he did stay with the idea of freedom that resisting the Compromise of 1850 had clarified for him until this idea developed into what was for his poetry, and perhaps for the intellectual life of nineteenth-century America, a deep consequence. ForWhitman's move towards celebrating the transpersonal possession of a possible self is, as Robert Pippin puts it in a slightly different context, the moment at which modernity might be said to answer the question of liberty with which it has defined itself. As Hegel explains the shift from freedom as autonomy to freedom as a transpersonal form of selfhood, the ultimate value of the individual has not been compromised at all - the idea has become rather that achieving the fullest recognition of the individual is not a question of justification and its negative dimension, the refusal to participate in communal life, but of self-expression and the capacity to make such expression available to others.

\section{Chapman University}

\section{NOTES}

1 Millie D. Jensen, "Whitman and Hegel: The Curious Triplicate Process." Walt Whitman Review 10 (June 1964), 27-34.

2 Walt Whitman, Notebooks and Unpublished Prose Manuscripts, ed. Edward F. Grier (New York: New York University Press, 1984), 6:2011.

3 Kathryne V. Lindberg, "Whitman's 'Convertible Terms."” Theorizing American Literature, ed. Bainard Cowan and Joseph G. Kronick (Baton Rouge: Louisiana State University Press, 1991), 239.

4 George B. Handley, New World Poetics: Nature and the Adamic Imagination of Whitman, Neruda, and Walcott (University of Georgia Press, 2007), 107.

5 Thomas F. Haddox, "Whitman's End of History: 'As I sat Alone by Blue Ontario's Shore,' Democratic Vistas, and Postbellum Politics of Nostalgia." Walt Whitman Quarterly Review 22 (Summer 2004), 4.

6 Stephen John Mack, The Pragmatic Whitman: Reimagining American Democracy (Iowa City: University of Iowa Press, 2002), 24.

7 As Kenneth Cmiel ("Whitman the Democrat," in David S. Reynolds, ed., $A$ Historical Guide to Walt Whitman [New York: Oxford University Press, 2000], 211-212) summarizes Whitman's political commitments in his early writing years:

Whitman [in the 1840s] believed in what twentieth-century political theorists have come to call "negative" liberty. A steady theme of his editorials was the need to guard against "meddlesome laws." He was adamant that government not regulate business. People should be "masters unto themselves," Whitman thought, for in "this wide and naturally rich country, the best government indeed is "that which governs least." We needed to carefully guard our individual rights, Whitman argued, for "man is the sovereign of his individual self." 
8 Walt Whitman, Leaves of Grass (1855), viii. Hereafter, $L G$ 1855. Available on the Walt Whitman Archive (www.whitmanarchive.org).

9 Robert Pippin, Modernism as a Philosophical Problem: On the Dissatisfactions of European High Culture (Cambridge: Basil Blackwell, 1991), 73.

10 Throughout this essay I have included the original German text alongside A. V. Miller's English translation. See G.W.F. Hegel, Phänomenologie des Geistes (Leipiz: Felix Meiner, 1921), 278-283 (hereafter, $P G$ ); and Hegel's Phenomenology of Spirit. trans. A.V. Miller (Oxford: Oxford University Press, 1977), 256-262 (hereafter, PS).

11 Alan Patten, Hegel's Idea of Freedom (Oxford: Oxford University Press, 1999), 259. 